\title{
ZnO Nanowire Application in Chemoresistive Sensing: A Review
}

\author{
Simas Rackauskas *, Nadia Barbero (D), Claudia Barolo (1) and Guido Viscardi \\ Department of Chemistry, NIS Interdepartmental Centre and INSTM Reference Centre, University of Turin, \\ Via Pietro Giuria 7, 10125 Turin, Italy; nadia.barbero@unito.it (N.B.); claudia.barolo@unito.it (C.B.); \\ guido.viscardi@unito.it (G.V.) \\ * Correspondence: simas.rackauskas@gmail.com; Tel.: +39-011-670-5323
}

Received: 30 September 2017; Accepted: 6 November 2017; Published: 9 November 2017

\begin{abstract}
This article provides an overview of the recent development of $\mathrm{ZnO}$ nanowires (NWs) for chemoresistive sensing. Working mechanisms of chemoresistive sensors are unified for gas, ultraviolet (UV) and bio sensor types: single nanowire and nanowire junction sensors are described, giving the overview for a simple sensor manufacture by multiple nanowire junctions. $\mathrm{ZnO} \mathrm{NW}$ surface functionalization is discussed, and how this effects the sensing is explained. Further, novel approaches for sensing, using $\mathrm{ZnO} \mathrm{NW}$ functionalization with other materials such as metal nanoparticles or heterojunctions, are explained, and limiting factors and possible improvements are discussed. The review concludes with the insights and recommendations for the future improvement of the $\mathrm{ZnO}$ NW chemoresistive sensing.
\end{abstract}

Keywords: ZnO; nanowire; sensors; chemoresistive; biosensing

\section{Introduction}

$\mathrm{ZnO}$ nanowires (NWs) have attracted a great deal of interest due to their exceptional properties. ZnO NWs, because of their biocompatibility, piezoelectricity, and optoelectronic properties, are applicable for various electronic, photonic, biological, and energy related applications [1-3]. The most attractive semiconducting properties of $\mathrm{ZnO}$ are wide bandgap $(3.37 \mathrm{eV})$, exciton binding energy $(60 \mathrm{meV})$, high refractive index which is higher than 2 and also many other features of $\mathrm{ZnO}$, including manufacturing techniques for high surface area, feasibility for wet chemical etching, structural stability and resistance to high-energy radiation. Moreover, $\mathrm{ZnO}$ has a tendency to form numerous nanostructures, because of the several fast grow directions available, which brings a diversity of methods for $\mathrm{ZnO}$ nanostructure synthesis, including by low-cost and low-temperature techniques. The potential is seen for application ultraviolet lasers [4], photodetectors [5], dye-sensitized solar cells [6,7], light-emitting diodes [8], and biomedical applications [9].

The names of $\mathrm{ZnO}$ nanomaterials such as nanowires [10] nanorods [11] or nanobelts [12] are used to characterize the shape of the obtained 1D material. ZnO NWs could be also grown in more sophisticated forms such as nanoforests [13], tetrapods [14-17], hierarchical nanowires [18], and many others [19-21] by simply controlling the crystal grow direction. $\mathrm{ZnO}$ nanowires are mostly grown by hydrothermal [22,23] or vapor transport methods [24,25]. A direct growth of $\mathrm{ZnO} N W$ on Zn metal is also attractive for its simplicity [26,27]. The variety of growth methods and availability of ZnO nanostructures gives a certain freedom to optimize $\mathrm{ZnO}$ NW sensors for the best surface reactivity and sensitivity.

ZnO NW application for sensing shows multiple advantages; especially interesting is a high surface ratio which provides an enhancement of the surface effects. Moreover, $\mathrm{ZnO}$ NWs are single crystals with a well-defined lattice, guiding to controlled reactions and providing stability. Comparing 
to polycrystalline structures, $\mathrm{ZnO} \mathrm{NW}$ response is typically faster due to the reaction on the NW surface and no need for inter-grain diffusion.

For the purpose of higher sensitivity and selectivity, $\mathrm{ZnO}$ NW sensor surface can be further modified or alternatively heterojunctions with other materials can be formed. Other forms of modification are NW morphology with the contact types or developing ZnO NW hybrid structures. Moreover, $\mathrm{ZnO}$ NW sensors can bring new functionalities with their flexible or stretchable configuration.

\section{ZnO Nanowire Sensors}

The main principle of sensing is to get a measurable response (mostly electrical) from the added substance. High sensitivity (response to extremely small amounts), selectivity (ability to differentiate between various substances) and linearity (response is linear amount of substance measured, or response can be described by other simple law) are the main parameters for efficient sensors. Additionally, there are practical requirements such as stability, simplicity of manufacture and measurement, low cost, biocompatibility and many others, which depend on the application field.

Recently, sensors which work on the change of electrical parameters (chemoresistive, electrochemical, bio-electrochemical) have drawn much attention, due to their multiple advantages, such as simple measurement and manufacturing, low cost, diverse functionalization possibilities just to name few. This class of sensors, employing $\mathrm{ZnO}$ as a base material, will be covered in this review.

In a broad sense, $\mathrm{ZnO}$ NW resistive sensors for $\mathrm{UV}$, gas and bio sensing have the same working principle: sensor response is related to the charge accumulated or transferred to NW. The working principle can be explained from the oxygen adsorption and desorption from the surface in gas sensors [28]. The mechanism is also attributed to $\mathrm{CuO}$ [29], $\mathrm{SnO}_{2}$ [16,30] and other metal oxides [31].

Most $\mathrm{ZnO} \mathrm{NW}$ sensors are n-type semiconductors, since $\mathrm{ZnO}$ is an intrinsically stable electron-dominated conductor [32]; it is challenging to incorporate acceptors for stable conduction properties, therefore $p$-type $\mathrm{ZnO}$ NWs are rare [33]. Considering the $n$-type case, when $\mathrm{ZnO}$ NWs are exposed to atmosphere, oxygen adsorbs on the surface and becomes negatively charged $\left(\mathrm{O}^{-}, \mathrm{O}^{2-}\right.$, or $\mathrm{O}_{2}{ }^{-}$) and extracts electrons from $\mathrm{ZnO}$. The surface region that loses electrons is defined as the surface charge depletion layer (Figure 1). The depletion layer controls the effective conduction channel and increases the energy barrier height of the contact to NW or NW-NW junctions. When exposed to reducing gas, such as $\mathrm{H}_{2} \mathrm{~S}, \mathrm{CO}$, and $\mathrm{NH}_{3}$, adsorbed $\mathrm{O}_{2}$ reacts with these gases and releases electrons back to the $\mathrm{ZnO}$, which increases the electrical conductivity. As the depletion layer thickness is related to the oxygen coverage, the presence of reducing gas can diminish the thickness of the depletion layer, which increases the overall conductivity of the $\mathrm{ZnO}$ NWs. In the same manner, the oxidizing gases such as $\mathrm{NO}_{2}$ and $\mathrm{O}_{3}$ generally decrease conductance by extracting more electrons from the surface and increasing the depletion layer width [28,34]. Similarly, as in gas sensors, UV sensor response is associated with the depletion layer width. Illuminating $\mathrm{ZnO} N W$ with a wavelength, higher than the bandgap, photogenerated holes combine with the negative $\mathrm{O}_{2}$ ions, inducing desorption and increasing the conductivity. In biosensors, typically the $\mathrm{ZnO} N W$ surface is covered with a material (e.g., enzyme) which attaches the targeted substance from the analyte; consequently, charge is transferred to $\mathrm{ZnO}$ NW, changing its depletion layer width. However, in the case of biosensors, attention is paid to the immobilization of biomolecules on the surface, as is described in Section 2.2. 


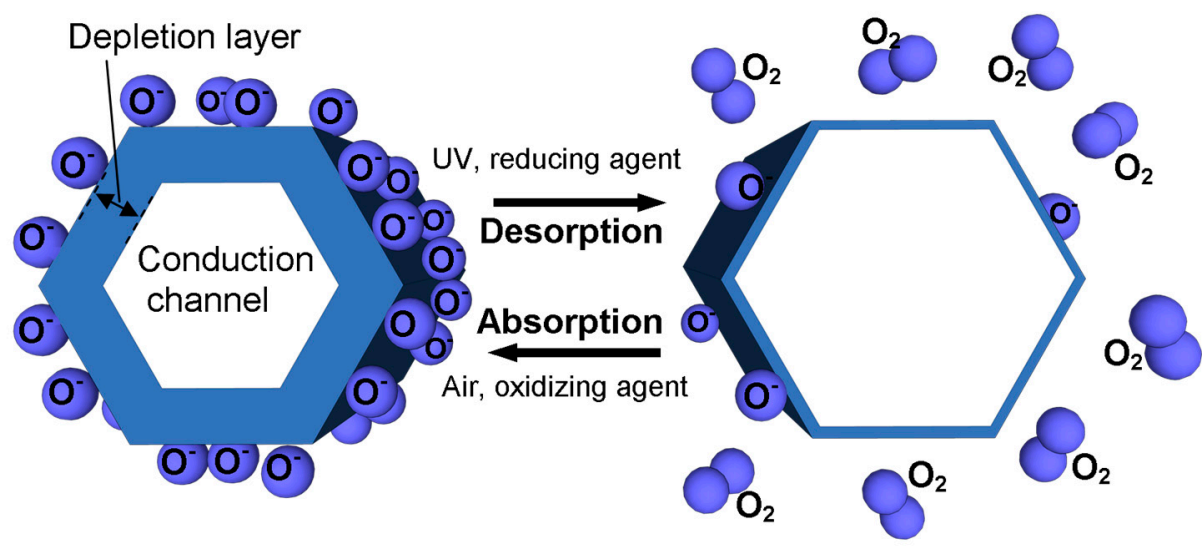

Figure 1. Schematics of unified $\mathrm{ZnO}$ nanowire (NW) chemoresistive sensing principle, based on the depletion layer width change with absorption-desorption of oxygen.

According to the device structure and working principle, nanowire sensors can be divided into two types: single nanowire connection and nanowire-nanowire junctions (Figure 2). Single connection devices rely on the response of a single NW, deposited or aligned between two metal contacts. Ohmic contacts are mostly used to contact $\mathrm{ZnO} \mathrm{NW}$; however, it is also possible to make Schottky contacts (e.g., contacting with Pt) in order to obtain a rectifying character or conduction [35]. However, most of research is done with NW-NW junction type of contacts, which is used not only because of the ease of sensor manufacture, but also due to the ability to control the barrier height. NW-NW junction sensors are typically more sensitive to small concentration changes, and have high rates of response as the conduction path involves tunneling through the depletion layer (Figure 2) [15]; however, in principle, single NW sensors can cover higher concentration ranges. Moreover, NW-NW junction integration into gas sensing devices is much more simple, as it relies on the randomly built conduction path between multiple NWs [15], whereas for the single NW sensors at least some degree of orientation is needed, wherefore ability to manipulate the NW or contacts is preferred [36].

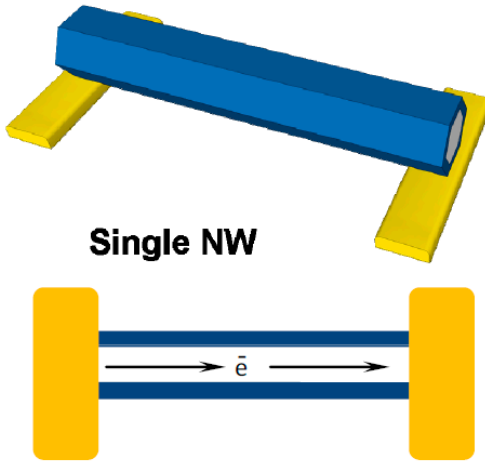

(a)

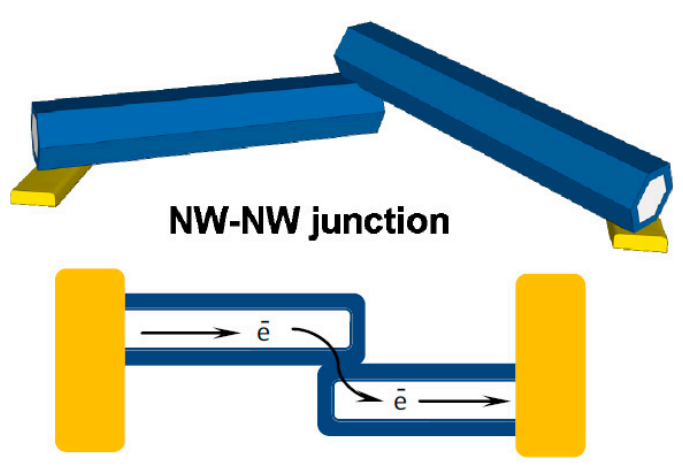

(b)

Figure 2. Schematics of ZnO NW sensor geometry types: (a) single NW; (b) NW-NW junction.

Selectivity is another important feature of the $\mathrm{ZnO}$ NW sensors, which is connected to the ability of the sensor to discriminate among different types of chemical species. While, in biosensors, different analytes can be targeted with a special biomolecule, it is an especially difficult task to differentiate among the same type of gases (oxidizing or reducing), since depletion layer width change and consequently response will be in the same direction. Selective recognition of the gases can be addressed by variations in chemical adsorption and dissociation of the target gases at the 
NW surface; therefore, NW sensor selectivity can be approached by several methods: NW geometry control [36,37], NW functionalization [38,39], selective contact formation [40], heterojunction [41], operating temperature modulation [42], and sensor array formation [43].

\section{1. $\mathrm{ZnO} \mathrm{NW}$ Heterojunction}

Heterojunction formation on $\mathrm{ZnO} \mathrm{NW}$, or simply a junction with other material, is mainly targeted to improve response and selectivity. A common choice for heterojunction is the use of metal oxides such as $\mathrm{SnO}_{2}$, because of high sensitivity. It was shown that $\mathrm{ZnO}$ NWs uniformly covered with the outer layer of $n$-type $\mathrm{SnO}_{2}$ nanoparticles [41] considerably improved the sensor response. Comparison of the gas sensor performance between $\mathrm{SnO}_{2}, \mathrm{ZnO} \mathrm{NW}$ and the formed $\mathrm{SnO} / \mathrm{ZnO}$ $\mathrm{NW}$ heterojunction showed that, after functionalization, $\mathrm{SnO}_{2} / \mathrm{ZnO} \mathrm{NW}$ sensor was responding at a high rate, selectivity and repeatability to $n$-butylamine gas was good, and therefore it can be applied

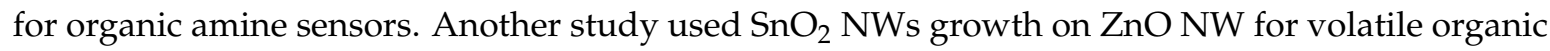
compound sensing [44]. Advantageous sensor performance comparing to the pure ZnO NWs was explained by potential barriers, which were forming at the $\mathrm{SnO}_{2} / \mathrm{ZnO}$. Moreover, the geometry of $\mathrm{SnO}_{2}$ nanowires affects the selectivity of triethylamine, toluene, ethanol, acetic acid, acetone, and methanol, allowing $\mathrm{ZnO} / \mathrm{SnO}_{2}$ heterostructures to discriminate acetone from other volatile compounds.

Another option is to use $\mathrm{ZnO} \mathrm{NW}$ heterojunction with $p$-type materials, forming local p-n junctions. Park et al. studied ZnO NW junction with $\mathrm{CuO}$ NW, by growing long crystalline nanowires and forming air-bridge-structured junction [45]. It was shown that formation of nanoscale $p$ - $n$ junctions lowers sensor conductance by two orders of magnitude (Figure 3). The current-voltage $\mathrm{I}-\mathrm{V}$ characteristics of both $\mathrm{ZnO} \mathrm{NW}$ and $\mathrm{CuO} \mathrm{NW}$ contacts were symmetric, while $\mathrm{ZnO} / \mathrm{CuO} \mathrm{NW}$ heterocontacts were asymmetric, which indicate the built-in potential established near the $p$ - $n$ junction. $P$-type material plays the role of catalyst and expands the adjacent electron depletion layer of $\mathrm{ZnO}$ NWs. However, sensitivity toward $\mathrm{H}_{2}, \mathrm{CO}$ and $\mathrm{NO}_{2}$ gases was lower of such $p$ - $n$ heterocontacts than $n$ - $n$ contact between $\mathrm{ZnO}$ NWs.
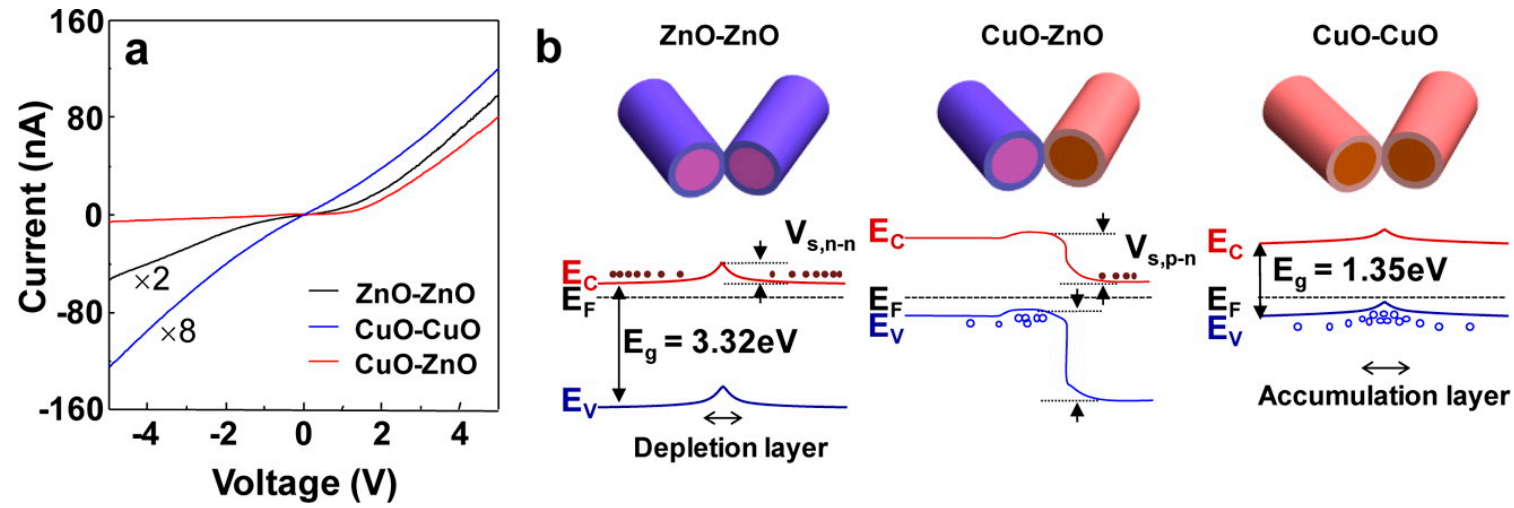

Figure 3. Comparison of contacts between $\mathrm{ZnO}$ and $\mathrm{CuO}$ NWs: (a) current-voltage (I-V) curves obtained at room temperature, demonstrating the characteristic nonlinear Schottky-like transport behavior; (b) Energy band diagram for every interconnection type between NWs. Reproduced with permission from [45]. Copyright American Chemical Society, 2013.

Zhang et al. reported an increased sensitivity of $\mathrm{ZnO} \mathrm{NW}$ with co-precipitated $p$-type $\mathrm{CuO}$ flower-type structure for ethanol vapor sensors [46]. The $\mathrm{ZnO} / \mathrm{uO}$ heterojunction demonstrates 2.5 times higher ethanol response at $300{ }^{\circ} \mathrm{C}$ compared to $\mathrm{ZnO} \mathrm{NWs}$ without $\mathrm{CuO}$. Good selectivity, long-term stability and also response and recovery time of 7 and $9 \mathrm{~s}$, respectively, were demonstrated. The improved ethanol response was also due to a widening of depletion layer on the $\mathrm{ZnO} / \mathrm{CuO}$ interface. 
In order to make a $p$ - $n$ heterojunction with $\mathrm{ZnO}$ NWs it is also possible to use other $p$ type metal oxides, such as $\mathrm{NiO}[47,48], \mathrm{Cr}_{2} \mathrm{O}_{3}[49,50], \mathrm{Mn}_{3} \mathrm{O}_{4}$ [51] or modify with $p$-typematerials, such as cobalt phthalocyanine (CoPc) [52].

UV sensor performance can also be enhanced applying ZnO NW heterojunctions with $p$ type oxides such as $\mathrm{CuO}$ [53] or $\mathrm{NiO}$ [54]. Ultrafast response to UV in $\mu$ s range was obtained at $\mathrm{ZnO} \mathrm{NW}$ contact with $p$-Si [55], which was explained by pyro-phototronic effect [56]. The pyro-phototronic results are from three elements: pyroelectric effect, photonic excitations, and semiconductor properties, the coupling of which paves a way to reach ultrafast photosensing performance with optoelectronic processes. Moreover, the response time of $\mathrm{ZnO}$ NW UV sensors decreases with increasing illumination intensity; thus, this could be potentially applied for ultrafast detection of intensive light.

Another interesting option is to decorate $\mathrm{ZnO}$ with noble metal particles. Metal nanoparticles can be employed to improve optical absorbance or emission in semiconductors, due to a high plasmon interaction with electromagnetic fields. ZnO NW gas sensing of ethanol can be improved by adding noble metallic nanoparticles, for example Au, Pt [57] or Ag [58]. Alternatively, a selective Pd contact with $\mathrm{ZnO} N W s$ [40] can be used for various gases such as $\mathrm{H}_{2}, \mathrm{CH}_{4}, \mathrm{H}_{2} \mathrm{~S}$ and $\mathrm{CO}_{2}$ at different operating temperatures, where high efficiency in hydrogen detection was reported. Moreover, Pt contacted $\mathrm{ZnO}$ NW networks can be used as self-powered UV sensors, since excellent photoresponse properties to $365 \mathrm{~nm}$ UV irradiation was obtained at zero bias [31].

\section{Combination of UV and Gas Sensing in ZnO NW}

The high operating temperatures (typically about $350^{\circ} \mathrm{C}$ ) are essential for gas detection and sensing, which is a major technical limitation in applicability. Moreover, adsorption of water on the $\mathrm{ZnO}$ surface leads to a decrease in surface potential, at relative humidity higher than $14 \%$ due to adsorbed water molecules increasing the surface electron density [59]. Irradiation of $\mathrm{ZnO}$ by photons with an energy greater than the band gap $(3.37 \mathrm{eV})$ changes adsorbed oxygen species on the surface, which is a practical alternative for achieving chemical reactions without the necessary heating. However, the UV activation shows an order of magnitude lower sensitivity compared to the same sensors activated by traditional heating methods [60]. UV activation, in order to increase the response, is used for $\mathrm{ZnO}$ films [59,61] and also for other materials [62,63]. A transparent $\mathrm{ZnO}$ NW sensor, which detects both UV and ethanol gas, was fabricated and deposited onto a silicon solar cell [64]. In UV sensing, the current rise was obtained in $137 \mathrm{~s}$. In ethanol vapor detection, UV was used for sensitivity improvement. The $\mathrm{ZnO}$ NW sensor response increased by $13 \%$ with an ethanol gas concentration change of $100 \mathrm{ppm}$ at $53{ }^{\circ} \mathrm{C}$ (heat generated by the c-Si solar cell). The sensor response is approximately zero without solar illumination.

Combining the response to chemical substance with a UV illumination, it is possible to get a synergy of these two effects and an increase of the performance of $\mathrm{ZnO} N W$ sensors (Figure 4); however, there are still only some studies on the combination of more than two effects on the performance of NW sensors. Synergistic effects of $\mathrm{Cr}_{2} \mathrm{O}_{3}$ functionalized $\mathrm{ZnO}$ NW sensor with UV irradiation were demonstrated for the ethanol gas sensing [65]. The responses at room temperature to ethanol were increased by UV illumination by 3.8 times for the pristine and by 7.7 times for $\mathrm{Cr}_{2} \mathrm{O}_{3}$ functionalized $\mathrm{ZnO}$ NW sensors. Moreover, the $\mathrm{Cr}_{2} \mathrm{O}_{3}$ modified $\mathrm{ZnO}$ NW sensor demonstrated rapid response and recovery; moreover, selectivity was also increased. This shows that combining heterostructures with $\mathrm{UV}$ activation has a synergistic effect on sensor performance. The synergistic effects arise from the $\mathrm{Cr}_{2} \mathrm{O}_{3}$ catalytic oxidation of ethanol and also from conduction channel width change due to $\mathrm{Cr}_{2} \mathrm{O}_{3}$ nanoparticle effect on ethanol adsorption and desorption under $\mathrm{UV}$ illumination in the $\mathrm{Cr}_{2} \mathrm{O}_{3}$ modified $\mathrm{ZnO}$ NW sensor. 

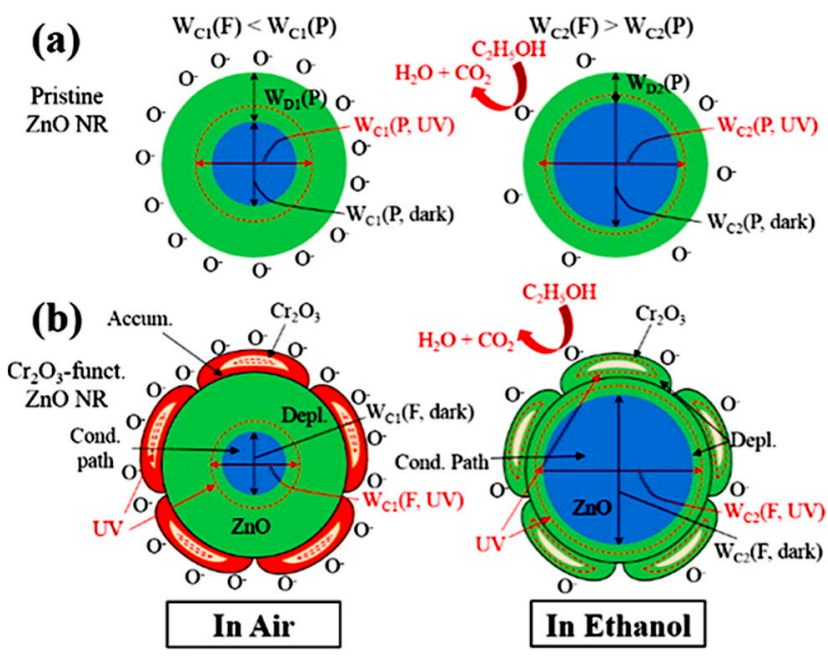

Figure 4. Schematic diagrams: (a) pristine $\mathrm{ZnO} \mathrm{NW}$; (b) $\mathrm{Cr}_{2} \mathrm{O}_{3}$-modified $\mathrm{ZnO} \mathrm{NW}$ in the dark and under UV illumination in air and ethanol showing the depletion layer and conduction path. Reproduced with permission from [65]. Copyright American Chemical Society, 2016.

Similarly, gold-decorated $\mathrm{ZnO}$ thin films showed improved sensing properties compared to bare $\mathrm{ZnO}$ under UV illumination. The sensor showed a selective response to $\mathrm{NO}_{2}$ gas under green light illumination. Moreover, $\mathrm{Au} / \mathrm{ZnO}$ sensor can detect $\mathrm{SO}_{2}$ gas in $\mathrm{ppm}$ level in humid conditions [66].

\section{2. $\mathrm{ZnO}$ Nanowire Biosensors}

We can identify three generations of biosensors [67]. In the first generation (Figure 5a), an electrical response is generated by the diffusion of the reaction products to the transducer. In the second generation (Figure $5 b$ ), instead, an initial redox reaction is performed by a mediator between the enzyme and its substrate. The enzyme and mediator are usually co-immobilized at an electrode surface in the third-generation of biosensors (Figure 5c); in this way, the biorecognition component is an integral part of the electrode transducer [68].

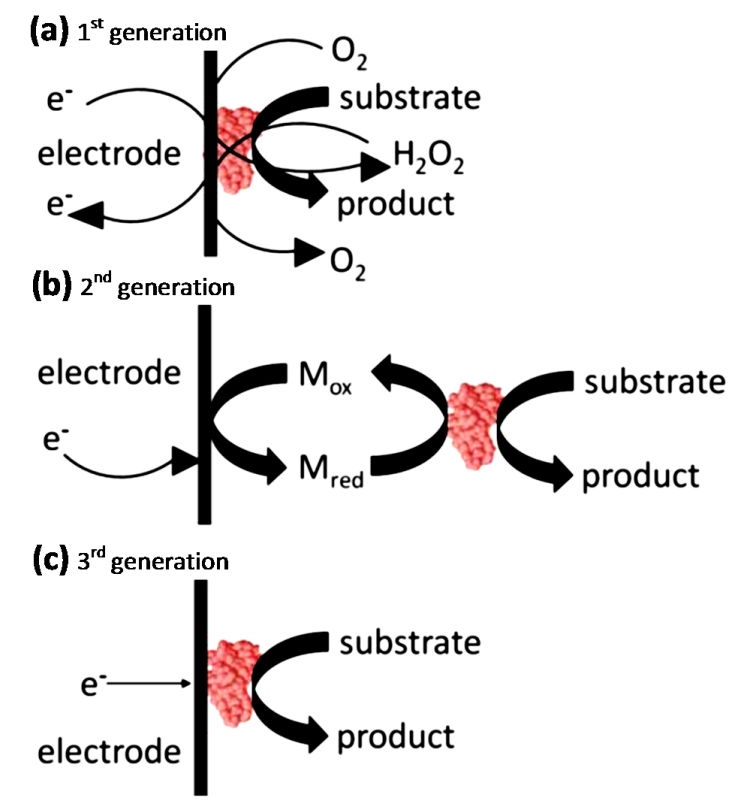

Figure 5. Schematic diagrams of three generations of sensors: (a) 1st generation; (b) 2nd generation and (c) 3rd generation [69]. 
Electronic devices based on semiconductor NW have emerged as a potential platform for the qualitative and quantitative detection of chemical and biological species due to their ultralow detection limit, fast readout and easy fabrication [70].

In particular, $\mathrm{ZnO}$ possesses a series of properties and characteristics (high electron mobility, easiness of fabrication of $\mathrm{ZnO}$, biocompatibility and low toxicity) that makes it a nice candidate for the construction of biosensors [71]. In particular, $\mathrm{ZnO}$ NWs, due to their low weight with extraordinary mechanical, electrical, thermal and multifunctional properties along with their high surface area, are suitable for adsorption or immobilization of various biomolecules such as proteins, enzymes or antibodies [9]. ZnO nanowires possess active surfaces that can be modified for the immobilization of a large number of biomolecules. These nanostructures can be perfect transducers for producing signals to interface with macroscopic instruments since they present diameters which are comparable to the sizes of the biological and chemical species being sensed [72]. Based on the specific feature of NW, biosensors may even go down to a single molecule detection [73].

Qualitative and quantitative detection of chemical and biological species is crucial in a huge variety of fields. If the literature on biosensors based on $\mathrm{ZnO}$ nanomaterials is quite rich, relatively few examples are focused on $\mathrm{ZnO}$ nanowires. Below, we will briefly summarize some recent findings reporting biosensors based on $\mathrm{ZnO}$ nanowires.

\subsubsection{Urea Biosensors}

The importance of urea measurements in blood and serum is important for a certain number of diseases. $\mathrm{ZnO}$ nanomaterials comprising nanorods and nanowires have been used for the fabrication of urea biosensors [9]. Well-aligned $\mathrm{ZnO}$ NW arrays were fabricated on gold-coated plastic substrates by using a low-temperature aqueous chemical growth (ACG) method and were proved to be sensitive to urea detection at a concentration from 0.1 to $100 \mathrm{mM}$ [74]. Urease was immobilized on the surface of the $\mathrm{ZnO}$ NWs using an electrostatic process. More recently, high quality $\mathrm{ZnO}$ NWs, synthesized by the chemical vapor deposition (CVD) method, were used for the fabrication of electrical biosensors based on field effect transistor (FET) for the simultaneously low and high concentrations detection of uric acid [73]. The obtained ZnO NW bioFET sensors could easily detect uric acid down to a concentration of $1 \mathrm{pM}$ with $14.7 \mathrm{nS}$ of conductance increase, and the response time turns out to be in the order of milliseconds.

\subsubsection{Glucose Biosensors}

Glucose is a critical metabolite for living organisms, particularly for patients who are suffering from diabetes, and glucose sensors attracted a huge amount of interest being one of the most important sensing technologies in medical science, clinical diagnostics, and food industry [75].

High-density vertical $\mathrm{ZnO}$ NWs were synthesized using the vapor-phase deposition method on patterned $\mathrm{Au}$ /glass electrode substrate with and without Au nanoparticle (NP) modification. A huge enhancement of the sensitivity toward glucose was obtained with Au NP modification [76]. A similar approach has been followed for the fabrication of high density, well-aligned $\mathrm{ZnO} N W$ s decorated with Pt nanoparticles to fabricate the working electrode for a non-enzymatic glucose biosensor [77]. $\mathrm{ZnO}$ NWs were synthesized hydrothermally on a glass substrate. The Pt NPs decoration allowed to enhance the biosensor's glucose sensitivity 10-fold in comparison with the pristine ZnO NWs electrode. The large specific surface area, abundant microspace, small channels, and high isoelectric point (IEP) fracture of $\mathrm{ZnO}$ enable effective fluid circulation and good biocompatibility boding well for immobilization of enzymes. These characteristics were exploited for the immobilization of glucose oxidase on a glucose enzymatic biosensor composed of $\mathrm{ZnO} N W s$ supported by silicon $\mathrm{NWs}(\mathrm{ZnO} / \mathrm{Si}$ NWs) [78]. A Si NWs/ZnO nanowire nanocomposites enzymatic biosensor exhibited very strong and sensitive amperometric responses to glucose, even in the presence of common interfering species, and showed a high sensitivity of $129 \mu \mathrm{A} \cdot \mathrm{mM}^{-1}$, low detection limit of $12 \mu \mathrm{M}$, and good stability as well as reproducibility. Very recently, a roll-to-roll flexographic printing technique was used for 
the fabrication of a three electrode electrochemical enzymatic biosensor consisting of ZnO NWs [79]. This biosensor device showed a typical sensitivity of $1.2 \pm 0.2 \mu \mathrm{A} \cdot \mathrm{mM}^{-1} \cdot \mathrm{cm}^{-2}$ with a linear response to the addition of glucose over a concentration range of 0.1 to $3.6 \mathrm{mM}$.

\subsubsection{DNA Detection}

Nanomaterials can provide good opportunities for sequence-specific target DNA detection as a medium for signal amplification. The possibility of using $\mathrm{ZnO} \mathrm{NWs}$ to fabricate electrochemical DNA biosensors was explored some years ago. In order to improve the sensitivity, multi-walled carbon nanotubes (MWCNTs) and gold nanoparticles (Au NPs) were employed. The resulting device was able to quantitatively detect target DNA from $1.0 \times 10^{-7}$ to $1.0 \times 10^{-13} \mathrm{M}$ with a detection limit of $3.5 \times 10^{-14} \mathrm{M}$ [80]. Another $\mathrm{ZnO} \mathrm{NWs} / \mathrm{Au}$ electrode showed to be a suitable platform for the immobilization of DNA for the rapid detection of a sequence specific for the breast cancer 1 (BRCA1) gene [81]. This DNA biosensor has the ability to detect the target sequence in the range of concentration between 10.0 and $100.0 \mu \mathrm{M}$ with a detection limit of $3.32 \mu \mathrm{M}$. A further sensitive and in situ selective label-free DNA sensor, based on a Schottky contacted ZnO NW device, has been fabricated. The performance of this device was significantly enhanced by the presence of piezotronic effect [82].

\section{Conclusions}

There is a growing interest in $\mathrm{ZnO} \mathrm{NW}$ application for sensing due to their high temperature stability, biocompatibility, simple synthesis route and sensor manufacture. In this review, we have summarized recent strategies to enhance $\mathrm{ZnO}$ NW sensor performance. Several conclusions could be made with the proposal for future trends:

- Many synthetic routes for ZnO NWs are already found, and different ZnO NW structures can be obtained by varying growth conditions. Decoration with metal particles is easily achieved; however, there is still a lack of comparative studies where the sensor performance is related not to the synthesis conditions but to the morphology of the sensor, namely the size of a conductive channel and how it is influenced by absorbed material.

- Heterojunction brings another possibility for the improvement of the sensing which can be achieved with comparingly facile fabrication techniques. Junctions with other $\mathrm{p}$ or $\mathrm{n}$ materials can be made with controlled surface coverage and thickness; still, there is a need to optimize $\mathrm{ZnO}$ NW interface with other materials in order to obtain high efficiency sensing.

- Using UV activation for bio and chemoresistive sensors shows considerable improvement in sensing. However, there is still a lack of understanding for the interplay of several effects (UV, temperature, oxygen adsorption, etc.), especially at the junctions of NW to NW or $p$ - $n$ junctions.

- $\quad$ The unique properties of ZnO NWs, simple fabrication and the possibility for suitable surface functionalization of the NWs make them exemplar as biosensor materials for a great variety of applications.

- The devices can be fabricated by roll-to-roll printing, which is suitable for low-cost high-volume production and a spread of large-scale commercialization of the biosensors.

Acknowledgments: The work has received funding from the European Union's Seventh Framework programme for research and innovation under the Marie Sklodowska-Curie grant agreement No 609402-2020 researchers: Train to Move (T2M).

Author Contributions: Simas Rackauskas worked on the ZnO nanowire sensors paragraphs while Nadia Barbero conceived and drafted the biosensor part. Claudia Barolo and Guido Viscardi coordinated and supervised the project. All authors analyzed and approved the final version of the manuscript.

Conflicts of Interest: The authors declare no conflict of interest. 


\section{References}

1. Zhang, Y. ZnO Nanostructures; Royal Society of Chemistry: Cambridge, UK, 2017; ISBN 978-1-78262-741-8.

2. Kołodziejczak-Radzimska, A.; Jesionowski, T. Zinc Oxide-From synthesis to application: A review. Materials 2014, 7, 2833-2881. [CrossRef] [PubMed]

3. Kaps, S.; Bhowmick, S.; Gröttrup, J.; Hrkac, V.; Stauffer, D.; Guo, H.; Warren, O.L.; Adam, J.; Kienle, L.; Minor, A.M.; et al. Piezoresistive response of quasi-one-dimensional $\mathrm{ZnO}$ nanowires using an In Situ electromechanical device. ACS Omega 2017, 2, 2985-2993. [CrossRef]

4. Chu, S.; Wang, G.; Zhou, W.; Lin, Y.; Chernyak, L.; Zhao, J.; Kong, J.; Li, L.; Ren, J.; Liu, J. Electrically pumped waveguide lasing from $\mathrm{ZnO}$ nanowires. Nat. Nanotechnol. 2011, 6, 506-510. [CrossRef] [PubMed]

5. Soci, C.; Zhang, A.; Xiang, B.; Dayeh, S.A.; Aplin, D.P.R.; Park, J.; Bao, X.Y.; Lo, Y.H.; Wang, D. ZnO nanowire UV photodetectors with high internal gain. Nano Lett. 2007, 7, 1003-1009. [CrossRef] [PubMed]

6. Rackauskas, S.; Barbero, N.; Barolo, C.; Viscardi, G. ZnO nanowires for dye sensitized solar cells. In Nanowires-New Insights; InTech: Rijeka, Croatia, 2017.

7. Znajdek, K.; Sibiński, M.; Lisik, Z.; Apostoluk, A.; Zhu, Y.; Masenelli, B.; Sędzicki, P. Zinc oxide nanoparticles for improvement of thin film photovoltaic structures' efficiency through down shifting conversion. Opto-Electron. Rev. 2017, 25, 99-102. [CrossRef]

8. Zhang, X.M.; Lu, M.Y.; Zhang, Y.; Chen, L.J.; Wang, Z.L. Fabrication of a high-brightness blue-light-emitting diode using a ZnO-Nanowire array grown on $p-G a N$ thin film. Adv. Mater. 2009, 21, 2767-2770. [CrossRef]

9. Zhang, Y.; Nayak, T.R.; Hong, H.; Cai, W. Biomedical applications of zinc oxide nanomaterials. Curr. Mol. Med. 2013, 13, 1633-1645. [CrossRef] [PubMed]

10. Rackauskas, S.; Nasibulin, A.G.; Jiang, H.; Tian, Y.; Statkute, G.; Shandakov, S.D.; Lipsanen, H.; Kauppinen, E.I. Mechanistic investigation of ZnO nanowire growth. Appl. Phys. Lett. 2009, 95, 183114. [CrossRef]

11. Rokhsat, E.; Akhavan, O. Improving the photocatalytic activity of graphene oxide/ZnO nanorod films by UV irradiation. Appl. Surf. Sci. 2016, 371, 592-595. [CrossRef]

12. Tarat, A.; Majithia, R.; Brown, R.A.; Penny, M.W.; Meissner, K.E.; Maffeis, T.G.G. Synthesis of nanocrystalline $\mathrm{ZnO}$ nanobelts via pyrolytic decomposition of zinc acetate nanobelts and their gas sensing behavior. Surf. Sci. 2012, 606, 715-721. [CrossRef]

13. Ko, S.H.; Lee, D.; Kang, H.W.; Nam, K.H.; Yeo, J.Y.; Hong, S.J.; Grigoropoulos, C.P.; Sung, H.J. Nanoforest of hydrothermally grown hierarchical $\mathrm{ZnO}$ nanowires for a high efficiency dye-sensitized solar cell. Nano Lett. 2011, 11, 666-671. [CrossRef] [PubMed]

14. Rackauskas, S.; Klimova, O.; Jiang, H.; Nikitenko, A.; Chernenko, K.A.; Shandakov, S.D.; Kauppinen, E.I.; Tolochko, O.V.; Nasibulin, A.G. A novel method for continuous synthesis of ZnO tetrapods. J. Phys. Chem. C 2015, 119, 16366-16373. [CrossRef]

15. Rackauskas, S.; Mustonen, K.; Järvinen, T.; Mattila, M.; Klimova, O.; Jiang, H.; Tolochko, O.; Lipsanen, H.; Kauppinen, E.I.; Nasibulin, A.G. Synthesis of $\mathrm{ZnO}$ tetrapods for flexible and transparent UV sensors. Nanotechnology 2012, 23, 95502. [CrossRef] [PubMed]

16. Mishra, Y.K.; Modi, G.; Cretu, V.; Postica, V.; Lupan, O.; Reimer, T.; Paulowicz, I.; Hrkac, V.; Benecke, W.; Kienle, L.; et al. Direct growth of freestanding $\mathrm{ZnO}$ tetrapod networks for multifunctional applications in photocatalysis, UV photodetection, and gas sensing. ACS Appl. Mater. Interfaces 2015, 7, 14303-14316. [CrossRef] [PubMed]

17. Gedamu, D.; Paulowicz, I.; Kaps, S.; Lupan, O.; Wille, S.; Haidarschin, G.; Mishra, Y.K.; Adelung, R. Rapid fabrication technique for interpenetrated $\mathrm{ZnO}$ nanotetrapod networks for fast UV sensors. Adv. Mater. 2014, 26, 1541-1550. [CrossRef] [PubMed]

18. Bielinski, A.R.; Kazyak, E.; Schlepütz, C.M.; Jung, H.J.; Wood, K.N.; Dasgupta, N.P. Hierarchical ZnO nanowire growth with tunable orientations on versatile substrates using atomic layer deposition seeding. Chem. Mater. 2015, 27, 4799-4807. [CrossRef]

19. Pugliese, D.; Bella, F.; Cauda, V.; Lamberti, A.; Sacco, A.; Tresso, E.; Bianco, S. A chemometric approach for the sensitization procedure of $\mathrm{ZnO}$ flowerlike microstructures for dye-sensitized solar cells. ACS Appl. Mater. Interfaces 2013, 5, 11288-11295. [CrossRef] [PubMed] 
20. Kuo, S.-Y.; Yang, J.-F.; Lai, F.-I. Improved dye-sensitized solar cell with a ZnO nanotree photoanode by hydrothermal method. Nanoscale Res. Lett. 2014, 9, 206. [CrossRef] [PubMed]

21. Zhang, S.; Chen, H.-S.; Matras-Postolek, K.; Yang, P. ZnO nanoflowers with single crystal structure towards enhanced gas sensing and photocatalysis. Phys. Chem. Chem. Phys. 2015, 17, 30300-30306. [CrossRef] [PubMed]

22. Lu, C.; Qi, L.; Yang, J.; Tang, L.; Zhang, D.; Ma, J. Hydrothermal growth of large-scale micropatterned arrays of ultralong ZnO nanowires and nanobelts on zinc substrate. Chem. Commun. 2006, 432, 3551-3553. [CrossRef] [PubMed]

23. Baruah, S.; Dutta, J. Hydrothermal growth of ZnO nanostructures. Sci. Technol. Adv. Mater. 2009, $10,013001$. [CrossRef] [PubMed]

24. Bae, S.Y.; Seo, H.W.; Park, J. Vertically aligned sulfur-doped $\mathrm{ZnO}$ nanowires synthesized via chemical vapor deposition. J. Phys. Chem. B 2004, 108, 5206-5210. [CrossRef]

25. Kuo, T.J.; Lin, C.N.; Kuo, C.L.; Huang, M.H. Growth of ultralong ZnO nanowires on silicon substrates by vapor transport and their use as recyclable photocatalysts. Chem. Mater. 2007, 19, 5143-5147. [CrossRef]

26. Rackauskas, S.; Nasibulin, A.G.; Jiang, H.; Tian, Y.; Kleshch, V.I.; Sainio, J.; Obraztsova, E.D.; Bokova, S.N.; Obraztsov, A.N.; Kauppinen, E.I. A novel method for metal oxide nanowire synthesis. Nanotechnology 2009, 20, 165603. [CrossRef] [PubMed]

27. Kleshch, V.I.; Rackauskas, S.; Nasibulin, A.G.; Kauppinen, E.I.; Obraztsova, E.D.; Obraztsov, A.N. Field emission properties of metal oxide nanowires. J. Nanoelectron. Optoelectron. 2012, 7, 35-40. [CrossRef]

28. Choi, K.J.; Jang, H.W. One-dimensional oxide nanostructures as gas-sensing materials: Review and issues. Sensors 2010, 10, 4083-4099. [CrossRef] [PubMed]

29. Lupan, O.; Cretu, V.; Postica, V.; Ababii, N.; Polonskyi, O.; Kaidas, V.; Schütt, F.; Mishra, Y.K.; Monaico, E.; Tiginyanu, I.; et al. Enhanced ethanol vapour sensing performances of copper oxide nanocrystals with mixed phases. Sens. Actuators B 2016, 224, 434-448. [CrossRef]

30. Paulowicz, I.; Hrkac, V.; Kaps, S.; Cretu, V.; Lupan, O.; Braniste, T.; Duppel, V.; Tiginyanu, I.; Kienle, L.; Adelung, R.; et al. Three-dimensional $\mathrm{SnO}_{2}$ nanowire networks for multifunctional applications: From high-temperature stretchable ceramics to ultraresponsive sensors. Adv. Electron. Mater. 2015, 1, 1500081. [CrossRef]

31. Bai, Z.; Yan, X.; Chen, X.; Zhao, K.; Lin, P.; Zhang, Y. High sensitivity, fast speed and self-powered ultraviolet photodetectors based on ZnO micro/nanowire networks. Prog. Nat. Sci. 2014, 24, 1-5. [CrossRef]

32. Lu, M.-P.; Lu, M.-Y.; Chen, L.-J. p-Type ZnO nanowires: From synthesis to nanoenergy. Nano Energy 2012, 1, 247-258. [CrossRef]

33. Yuan, G.D.; Zhang, W.J.; Jie, J.S.; Fan, X.; Zapien, J.A.; Leung, Y.H.; Luo, L.B.; Wang, P.F.; Lee, C.S.; Lee, S.T. p-type ZnO nanowire arrays. Nano Lett. 2008, 8, 2591-2597. [CrossRef] [PubMed]

34. Chen, J.; Wang, K.; Cao, B.; Zhou, W. Highly sensitive and selective gas detection by 3D metal oxide nanoarchitectures. In Three-Dimensional Nanoarchitectures; Springer: New York, NY, USA, 2011; pp. 391-412. ISBN 978-1-4419-9822-4.

35. Bercu, B.; Geng, W.; Simonetti, O.; Kostcheev, S.; Sartel, C.; Sallet, V.; Lérondel, G.; Molinari, M.; Giraudet, L.; Couteau, C. Characterizations of Ohmic and Schottky-behaving contacts of a single ZnO nanowire. Nanotechnology 2013, 24, 415202. [CrossRef] [PubMed]

36. Schütt, F.; Postica, V.; Adelung, R.; Lupan, O. Single and networked ZnO-CNT hybrid tetrapods for selective room-temperature high-performance ammonia sensors. ACS Appl. Mater. Interfaces 2017, 9, 23107-23118. [CrossRef] [PubMed]

37. Sysoev, V.V.; Strelcov, E.; Sommer, M.; Bruns, M.; Kiselev, I.; Habicht, W.; Kar, S.; Gregoratti, L.; Kiskinova, M.; Kolmakov, A. Single-nanobelt electronic nose: Engineering and tests of the simplest analytical element. ACS Nano 2010, 4, 4487-4494. [CrossRef] [PubMed]

38. Lupan, O.; Postica, V.; Gröttrup, J.; Mishra, A.K.; de Leeuw, N.H.; Carreira, J.F.C.; Rodrigues, J.; Ben Sedrine, N.; Correia, M.R.; Monteiro, T.; et al. Hybridization of Zinc oxide tetrapods for selective gas sensing applications. ACS Appl. Mater. Interfaces 2017, 9, 4084-4099. [CrossRef] [PubMed]

39. Sun, G.-J.; Lee, J.K.; Choi, S.; Lee, W.I.; Kim, H.W.; Lee, C. Selective oxidizing gas sensing and dominant sensing mechanism of $n$-CaO-decorated $n-\mathrm{ZnO}$ nanorod sensors. ACS Appl. Mater. Interfaces 2017, 9, 9975-9985. [CrossRef] [PubMed] 
40. Kumar, M.; Singh Bhati, V.; Ranwa, S.; Singh, J.; kumar, M. Pd/ZnO nanorods based sensor for highly selective detection of extremely low concentration hydrogen. Sci. Rep. 2017, 7, 236. [CrossRef] [PubMed]

41. Wang, L.; Li, J.; Wang, Y.; Yu, K.; Tang, X.; Zhang, Y.; Wang, S.; Wei, C. Construction of $1 \mathrm{D} \mathrm{SnO}_{2}$-coated ZnO nanowire heterojunction for their improved $n$-butylamine sensing performances. Sci. Rep. 2016, 6, 35079. [CrossRef] [PubMed]

42. Li, F.-A.; Jin, H.; Wang, J.; Zou, J.; Jian, J. Selective sensing of gas mixture via a temperature modulation approach: New strategy for potentiometric gas sensor obtaining satisfactory discriminating features. Sensors 2017, 17, 573. [CrossRef] [PubMed]

43. Fedorov, F.; Vasilkov, M.; Lashkov, A.; Varezhnikov, A.; Fuchs, D.; Kübel, C.; Bruns, M.; Sommer, M.; Sysoev, V. Toward new gas-analytical multisensor chips based on titanium oxide nanotube array. Sci. Rep. 2017, 7, 9732. [CrossRef] [PubMed]

44. Rakshit, T.; Santra, S.; Manna, I.; Ray, S.K. Enhanced sensitivity and selectivity of brush-like $\mathrm{SnO}_{2}$ nanowire/ZnO nanorod heterostructure based sensors for volatile organic compounds. RSC Adv. 2014, 4, 36749-36756. [CrossRef]

45. Park, W.J.; Choi, K.J.; Kim, M.H.; Koo, B.H.; Lee, J.-L.; Baik, J.M. Self-assembled and highly selective sensors based on air-bridge-structured nanowire junction arrays. ACS Appl. Mater. Interfaces 2013, 5, 6802-6807. [CrossRef] [PubMed]

46. Zhang, Y.-B.; Yin, J.; Li, L.; Zhang, L.-X.; Bie, L.-J. Enhanced ethanol gas-sensing properties of flower-like $p-\mathrm{CuO} / n-\mathrm{ZnO}$ heterojunction nanorods. Sens. Actuators B 2014, 202, 500-507. [CrossRef]

47. Ju, D.; Xu, H.; Qiu, Z.; Guo, J.; Zhang, J.; Cao, B. Highly sensitive and selective triethylamine-sensing properties of nanosheets directly grown on ceramic tube by forming $\mathrm{NiO} / \mathrm{ZnO}$ PN heterojunction. Sens. Actuators B 2014, 200, 288-296. [CrossRef]

48. Na, C.W.; Woo, H.-S.; Lee, J.-H.; Yao, P.J.; Nishibori, M.; Wang, D.; Wang, C.; Pinna, N.; Lee, J.H. Design of highly sensitive volatile organic compound sensors by controlling $\mathrm{NiO}$ loading on $\mathrm{ZnO}$ nanowire networks. RSC Adv. 2012, 2, 414-417. [CrossRef]

49. Woo, H.-S.; Na, C.W.; Kim, I.-D.; Lee, J.-H. Highly sensitive and selective trimethylamine sensor using one-dimensional $\mathrm{ZnO}-\mathrm{Cr}_{2} \mathrm{O}_{3}$ hetero-nanostructures. Nanotechnology 2012, 23, 245501. [CrossRef] [PubMed]

50. Park, S.; Kim, S.; Kheel, H.; Lee, C. Oxidizing gas sensing properties of the $n-\mathrm{ZnO} / p-\mathrm{Co}_{3} \mathrm{O}_{4}$ composite nanoparticle network sensor. Sens. Actuators B 2015, 222, 1193-1200. [CrossRef]

51. Na, C.W.; Park, S.Y.; Chung, J.H.; Lee, J.H. Transformation of $\mathrm{ZnO}$ nanobelts into single-crystalline $\mathrm{Mn}_{3} \mathrm{O}_{4}$ nanowires. ACS Appl. Mater. Interfaces 2012, 4, 6565-6572. [CrossRef] [PubMed]

52. Kumar, A.; Samanta, S.; Singh, A.; Roy, M.; Singh, S.; Basu, S.; Chehimi, M.M.; Roy, K.; Ramgir, N.; Navaneethan, M.; et al. Fast response and high sensitivity of $\mathrm{ZnO}$ nanowires-cobalt phthalocyanine heterojunction based $\mathrm{H}_{2} \mathrm{~S}$ sensor. ACS Appl Mater. Interfaces 2015, 7, 17713-17724. [CrossRef] [PubMed]

53. Wu, J.-K.; Chen, W.-J.; Chang, Y.H.; Chen, Y.F.; Hang, D.-R.; Liang, C.-T.; Lu, J.-Y. Fabrication and photoresponse of $\mathrm{ZnO}$ nanowires/CuO coaxial heterojunction. Nanoscale Res. Lett. 2013, 8, 387. [CrossRef] [PubMed]

54. Li, Y.-R.; Wan, C.-Y.; Chang, C.-T.; Tsai, W.-L.; Huang, Y.-C.; Wang, K.-Y.; Yang, P.-Y.; Cheng, H.-C. Thickness effect of $\mathrm{NiO}$ on the performance of ultraviolet sensors with $p-\mathrm{NiO} / n-\mathrm{ZnO}$ nanowire heterojunction structure. Vacuum 2015, 118, 48-54. [CrossRef]

55. Wang, Z.; Yu, R.; Wang, X.; Wu, W.; Wang, Z.L. Ultrafast response $p$-Si $/ n$-ZnO heterojunction ultraviolet detector based on pyro-phototronic effect. Adv. Mater. 2016, 28, 6880-6886. [CrossRef] [PubMed]

56. Wang, Z.; Yu, R.; Pan, C.; Li, Z.; Yang, J.; Yi, F.; Wang, Z.L. Light-induced pyroelectric effect as an effective approach for ultrafast ultraviolet nanosensing. Nat. Commun. 2015, 6, 8401. [CrossRef] [PubMed]

57. Liu, X.; Zhang, J.; Guo, X.; Wu, S.; Wang, S. Amino acid-assisted one-pot assembly of Au, Pt nanoparticles onto one-dimensional ZnO microrods. Nanoscale 2010, 2, 1178-1184. [CrossRef] [PubMed]

58. Ding, J.; Zhu, J.; Yao, P.; Li, J.; Bi, H.; Wang, X. Synthesis of ZnO-Ag hybrids and their gas-sensing performance toward ethanol. Ind. Eng. Chem. Res. 2015, 54, 8947-8953. [CrossRef]

59. Jacobs, C.B.; Maksov, A.B.; Muckley, E.S.; Collins, L.; Mahjouri-Samani, M.; Ievlev, A.; Rouleau, C.M.; Moon, J.-W.; Graham, D.E.; Sumpter, B.G.; et al. UV-activated ZnO films on a flexible substrate for room temperature $\mathrm{O}_{2}$ and $\mathrm{H}_{2} \mathrm{O}$ sensing. Sci. Rep. 2017, 7, 6053. [CrossRef] [PubMed] 
60. Alenezi, M.R.; Alshammari, A.S.; Jayawardena, K.D.G.I.; Beliatis, M.J.; Henley, S.J.; Silva, S.R.P. Role of the exposed polar facets in the performance of thermally and UV activated $\mathrm{ZnO}$ nanostructured gas sensors. J. Phys. Chem. C 2013, 117, 17850-17858. [CrossRef] [PubMed]

61. Fan, S.-W.; Srivastava, A.K.; Dravid, V.P. UV-activated room-temperature gas sensing mechanism of polycrystalline ZnO. Appl. Phys. Lett. 2009, 95, 142106. [CrossRef]

62. Comini, E.; Cristalli, A.; Faglia, G.; Sberveglieri, G. Light enhanced gas sensing properties of indium oxide and tin dioxide sensors. Sens. Actuators B 2000, 65, 260-263. [CrossRef]

63. Gromova, Y.; Alaferdov, A.; Rackauskas, S.; Ermakov, V.; Orlova, A.; Maslov, V.; Moshkalev, S.; Baranov, A.; Fedorov, A. Photoinduced electrical response in quantum dots/graphene hybrid structure. J. Appl. Phys. 2015, 118, 104305. [CrossRef]

64. Lin, C.H.; Chang, S.-J.J.; Chen, W.-S.; Hsueh, T.-J.J. Transparent ZnO-nanowire-based device for UV light detection and ethanol gas sensing on c-Si solar cell. RSC Adv. 2016, 6, 42-54. [CrossRef]

65. Park, S.; Sun, G.-J.; Jin, C.; Kim, H.W.; Lee, S.; Lee, C. Synergistic effects of a combination of $\mathrm{Cr}_{2} \mathrm{O}_{3}$-Functionalization and UV-irradiation techniques on the ethanol gas sensing performance of $\mathrm{ZnO}$ nanorod gas sensors. ACS Appl. Mater. Interfaces 2016, 8, 2805-2811. [CrossRef] [PubMed]

66. Gaiardo, A.; Fabbri, B.; Giberti, A.; Guidi, V.; Bellutti, P.; Malagu, C.; Valt, M.; Pepponi, G.; Gherardi, S.; Zonta, G.; et al. $\mathrm{ZnO}$ and $\mathrm{Au} / \mathrm{ZnO}$ thin films: Room-temperature chemoresistive properties for gas sensing applications. Sens. Actuators B 2016, 237, 1085-1094. [CrossRef]

67. Zhu, P.; Weng, Z.; Li, X.; Liu, X.; Wu, S.; Yeung, K.W.K.; Wang, X.; Cui, Z.; Yang, X.; Chu, P.K. Biomedical applications of functionalized $\mathrm{ZnO}$ nanomaterials: From biosensors to bioimaging. Adv. Mater. Interfaces 2016, 3, 1500494. [CrossRef]

68. Ronkainen, N.J.; Halsall, H.B.; Heineman, W.R. Electrochemical biosensors. Chem. Soc. Rev. 2010, 39, 1747-1763. [CrossRef] [PubMed]

69. Putzbach, W.; Ronkainen, N.J. Immobilization techniques in the fabrication of nanomaterial-based electrochemical biosensors: A review. Sensors 2013, 13, 4811-4840. [CrossRef] [PubMed]

70. Zhu, C.; Yang, G.; Li, H.; Du, D.; Lin, Y. Electrochemical sensors and biosensors based on nanomaterials and nanostructures. Anal. Chem. 2015, 87, 230-249. [CrossRef] [PubMed]

71. Xu, C.X.; Yang, C.; Gu, B.X.; Fang, S.J. Nanostructured ZnO for biosensing applications. Chin. Sci. Bull. 2013, 58, 2563-2566. [CrossRef]

72. Choi, A.; Kim, K.; Jung, H.I.; Lee, S.Y. ZnO nanowire biosensors for detection of biomolecular interactions in enhancement mode. Sens. Actuators B 2010, 148, 577-582. [CrossRef]

73. Liu, X.; Lin, P.; Yan, X.; Kang, Z.; Zhao, Y.; Lei, Y.; Li, C.; Du, H.; Zhang, Y. Enzyme-coated single ZnO nanowire FET biosensor for detection of uric acid. Sens. Actuators B 2013, 176, 22-27. [CrossRef]

74. Ali, S.M.U.; Ibupoto, Z.H.; Salman, S.; Nur, O.; Willander, M.; Danielsson, B. Selective determination of urea using urease immobilized on $\mathrm{ZnO}$ nanowires. Sens. Actuators B 2011, 160, 637-643. [CrossRef]

75. Yu, R.; Pan, C.; Chen, J.; Zhu, G.; Wang, Z.L. Enhanced performance of a ZnO nanowire-based self-powered glucose sensor by piezotronic effect. Adv. Funct. Mater. 2013, 23, 5868-5874. [CrossRef]

76. Lin, S.Y.; Chang, S.J.; Hsueh, T.J. ZnO nanowires modified with Au nanoparticles for nonenzymatic amperometric sensing of glucose. Appl. Phys. Lett. 2014, 104, 193704. [CrossRef]

77. Hsu, C.L.; Lin, J.H.; Hsu, D.X.; Wang, S.H.; Lin, S.Y.; Hsueh, T.J. Enhanced non-enzymatic glucose biosensor of $\mathrm{ZnO}$ nanowires via decorated Pt nanoparticles and illuminated with UV/green light emitting diodes. Sens. Actuators B 2017, 238, 150-159. [CrossRef]

78. Miao, F.; Lu, X.; Tao, B.; Li, R.; Chu, P.K. Glucose oxidase immobilization platform based on ZnO nanowires supported by silicon nanowires for glucose biosensing. Microelectron. Eng. 2016, 149, 153-158. [CrossRef]

79. Fung, C.M.; Lloyd, J.S.; Samavat, S.; Deganello, D.; Teng, K.S. Facile fabrication of electrochemical ZnO nanowire glucose biosensor using roll to roll printing technique. Sens. Actuators B 2017, 247, 807-813. [CrossRef]

80. Wang, J.; Li, S.; Zhang, Y. A sensitive DNA biosensor fabricated from gold nanoparticles, carbon nanotubes, and zinc oxide nanowires on a glassy carbon electrode. Electrochim. Acta 2010, 55, 4436-4440. [CrossRef] 
81. Mansor, N.A.; Zain, Z.M.; Hamzah, H.H.; Noorden, M.S.A.; Jaapar, S.S.; Beni, V.; Ibupoto, Z.H. Detection of Breast Cancer 1 (BRCA1) gene using an electrochemical DNA biosensor based on immobilized ZnO nanowires. Open J. Appl. Biosens. 2014, 3, 9-17. [CrossRef]

82. Cao, X.; Cao, X.; Guo, H.; Li, T.; Jie, Y.; Wang, N.; Wang, Z.L. Piezotronic effect enhanced label-free detection of DNA using a schottky-contacted ZnO nanowire biosensor. ACS Nano 2016, 10, 8038-8044. [CrossRef] [PubMed] 